\title{
Emotion Disorder Screening in a Confirmed-Positive Case in Covid-19 Patient Undergoing Self-Isolation
}

\author{
Sri Quintina Indriyana* \\ Department of Public Health, Medicine Faculty \\ Universitas Jenderal Achmad Yani \\ Cimahi, Indonesia \\ *sri.quintina@gmail.com
}

\begin{abstract}
It has been almost one year since Indonesia reported the first case of COVID-19 on $2^{\text {nd }}$ of March 2020 followed with its fast spreading throughout Indonesia. This period of COVID-19 pandemic has become a high stressor and impacted physically and psychologically for every individual, in particular for the people who have to undergo self isolation due to COVID-19. Most of the infected people are isolated at home to prevent the transmission of the virus, and there are also some people who isolate themselves at the place referred by the government. This case is aimed to raise the medical staff's awareness of emotion disorder in confirmed positive case COVID-19. A man of 23 years old, having a contact history with a confirmed-positive case, was confirmed positive after having a swab PCR examination. The patient, supported by his family, was ready to self isolate at home, but as the patient had his fear of infecting the other members of the family, he underwent the self isolation in a hospital for self isolation recommended by the government. The screening with Patient's Health Questionnaire 9 (PHQ-9) and Generalized Anxiety Disorder 7 (GAD-7) showed that the patient was under mild depression $($ PHQ-9 score $=5$ ) and medium anxiety (GAD-7 score $=13$ ). The complaints felt by the patient among others were anxiety, worry, nervousness, short temper, and feeling that something bad might happen. Other complaints were his loss of interests in doing any activity, trouble sleeping, fatigue, loss of appetite, and difficulty concentrating. Emotional mental disorders could also happen due to COVID-19 pandemic. The patient needed not only medical treatment but also psychological support from both a medical caregiver and family.
\end{abstract}

Keywords-COVID-19, emotional disorder, self isolation, screening

\section{INTRODUCTION}

Corona Virus Disease 2019 (COVID-19) has spread throughout the world since it was found for the first time in Wuhan, China on $31^{\text {st }}$ December 2019. Indonesia reported the first case on $2^{\text {nd }}$ of March 2020 and the disease spread rapidly throughout the nation [1]. COVID-19 may cause symptoms so severe that they can cause death. Clinical manifestation of COVID-19 infection ranges from no sign (asymptomatic) to severe pneumonia with respiratory distress syndrome condition, septic shock, and multi organ failure [2]. The number of additional positive cases of COVID-19 in Indonesia reached 11,278 people, and the death rate due to COVID-19 was 24,951 people [3].

Corona virus infects human respiratory tract and is believed that its transmission is from human to human, especially through droplets produced when an infected person coughs or sneezes. These droplets may enter the mouth or nose of those around this infected person, or maybe they are inhaled into the lungs $[1,2,4]$. The transmission can also happen through an object and surface contaminated with droplets in the surrounding of the person infected. Therefore, the transmission of COVID-19 can take place through direct contact with the infected person and indirect contact with the surface or object used by the infected persons $[1,5]$.

The incubation period of COVID-19 in average will take 5-6 days, with a range between 1 and 14 days, but it can reach up to14 days. The highest transmission risk is obtained during the first days of the disease due to high concentrations of the virus in secretions. The infected person can directly infect others up to 48 hours before the onset of the symptoms (presymptomatic) and up to 14 days after the onset of the symptoms. A study reported that $12.6 \%$ showed presymptomatic transmission. It is important to know the period of presymptomatic as it enables the transmission of the virus through droplets or contacts with contaminated objects. In addition, there are asymptomatic confirmed cases, even though the risk of transmission is very low but there is still a small chance for the transmission to happen [1]. It is estimated that $68.4 \%$ of all COVID-19 infection is caused by the virus transmission before the symptoms appear [6].

Not all cases of COVID-19 confirmed cases need to be treated in hospital, the sufferers who are not included in the vulnerable group can simply self-isolate independently at home. The importance of independent self-isolation for approximately 14 days is because the COVID-19 symptoms will appear within the span of time through coughing, fever, or shortness of breath. During that interval, the conditions of those who are suspected to get infected with COVID-19 are isolated and monitored in hospital, house, or other places [7]. Self isolation is an effort to prevent the transmission of 
COVID-19 by staying at home while monitoring one's condition and still keeping the distance safe for the other members in the family. Those who need to self isolate are the people who have the disease symptoms like fever, cough or runny nose, sore throat, or other respiratory disease symptoms [8].

The period of COVID-19 pandemic contributed to declining mental health for each person, or a group of people or the community at large. This is because COVID-19 pandemic becomes a severe stressor [9]. This condition gives physical and psychological impact to every individual, in particular the people that have to self isolate/quarantine because of COVID19. When COVID-19 emerged in China by the end of 2019, most of the population were quarantined at home to prevent the transmission of the virus. This condition is almost similar to that in Indonesia, some self quarantined at home, some others are quarantined at home/places recommended by the government. After experiencing clinical disorders like some of COVID-19 symptoms, the patient has to make a separate treatment, which is monitored regularly by a medical worker. During the isolation, the patients are confronted with a situation, which is strictly watched. This makes lack of faceto-face communication, depression, and anxiety $[9,10]$.

Anxiety is a condition of helplessness, insecure feeling, an inability of facing the environment demand. Mental health means emotional and psychological health in which one can use his or her thoughts and ability, have a function in the society, and fulfil daily needs. Mental disorder is caused by some traumatic experiences, like anxiety and over-fear, disturbing conflicts, which makes it difficult to the soul of the individual. Emotional mental disorder is a condition which states that an individual who experiences a change in emotional state can develop into a continuous pathological state. Emotional mental disorder can happen due to COVID-19 pandemic. Emotional disorder problem experienced by a person confirmed to be COVID-19 positive come from not only themselves, but also their surrounding. This can add to the list of impacts caused by COVID-19 pandemic. The condition will worsen if not detected early on and handled well [11].

\section{CASE}

There was a case of a 23-year old man who previously had a contact history with a positive confirmed case of COVID-19. Three days after the contact, the patients suffered from fever with the temperature of $39-40^{\circ} \mathrm{C}$, cough, sore throat, runny nose, and breathing discomfort. The patient had no history of diseases like hypertension, diabetes mellitus, or tuberculosis so that the patient was free from comorbid status. The patient then performed antigen swab test with reactive result and was instructed by the doctor to self-isolate at home and reported to the Community Health Centre based on his domicile. The following day the patient was tested for the Reverse Transcriptase-Polymerase Chain Reaction (RT-PCR) test at the Community Health Centre. After three days the result of
RT-PCR swab test was issued stating a positive result with Cycle Threshold value (CT-value) 21.

The readiness at the patient's home for self-isolation met the requirements, among others there were special room with windows for air exchange and sunlight exposure into the room, a special bathroom separated from the other members of the family, the family was able to provide medicine and food, and it was possible to have an online consultation with the health officer, but with the consideration of his fearing of infecting the other members of the family, the patient moved to a SelfIsolation Hospital in accordance with the procedure given by the community health centre. After 4-day self-isolation at home, the patient then moved to a Self-Isolation Hospital allocated by the government for 10 days.

The condition of the patient on day 5 showed some improvement that the fever was gone and the sense of olfactory and taste at the tongue started to recover, but there was still coughing. During his stay in the hospital, the patient's condition was monitored on a daily basis by the officer in charge comprising body temperature monitor, blood pressure examination, and anamnesis on the condition he felt. The patient was given food 3 times a day, allowed to leave the room in the morning to do sports together with other patients by turn, and sunbathed everyday between $9-10$ am in the morning. The patient took Avigan, Azitromisin, and multivitamin. One week after the patient's self-isolation, the patient repeated the RTPCR swab test with still positive results (CT Value 32). On day -14 of self isolation, the patient took RT-PCR swab test and the result tested negative.

\section{DISCUSSION}

The patient showed the clinical signs on day 3 after having a contact with a person with positive confirmed Covid-19. The clinical signs experienced by the patient were fever, cough, runny nose, sore throat, and this corresponds to Covid-19 incubation period, which takes 1-14 days, and in general it happens on day 3 up to day 7. Fever, fatigue, and dry cough are the general signs of corona infection along with the symptoms like nasal congestion, runny nose, and diarrhea in some patients [1]. The patient's condition lied under Covid-19 confirmed case that did not need the treatment in the hospital and it was enough with self isolation at home or other places meeting the requirement for self-isolation [7]. Those who need to self-isolate are the patients with the symptoms like fever, cough or runny nose, sore throat, or other respiratory disease symptoms [8].

Self-isolation refers to the separation of ill persons with contagious diseases from others for the purpose of protecting non- infected persons. For infected people, self- isolation usually occurs in hospital settings under the care of medical professions [12]. Moreover, it is advised for patients to be situated in a private negative pressure room with airbornedroplet-contact precautions in order to prevent transmissions via aerosols [13]. For other people who are still not infected, it 
requires staying apart from the infected ones for the prevention of receiving the disease.

During self-isolation food-utensil, shower, and clothes sharing with the other members of the family is strictly prohibited. If the person needs to share the bathroom or washing machine, the application of disinfectant is a must after the use. To keep body's defense during self isolation is done by applying a healthy lifestyle, which is to eat balanced nutritious diet, consume more fruit and vegetables, get enough rest, do light exercises, and avoid smoking or drink alcohol drink [8,14]

Table 1 shows the patient's family's health condition regarding the Covid-19 problem. The health condition of the patient's family is under a good condition, there was no health problem like the ones suffered by the patient or the signs of Covid-19.

TABLE I. THE DESCRIPTION ON THE CONDITION OF THE PATIENT AND HIS FAMILY

\begin{tabular}{|c|c|c|c|}
\hline No & Questions & Yes & No \\
\hline 1. & $\begin{array}{l}\text { Is there any member of the family with a health } \\
\text { problem like what you have or like the } \\
\text { symptoms of Covid-19? }\end{array}$ & & $\sqrt{ }$ \\
\hline 2. & $\begin{array}{l}\text { Does your family think that your health } \\
\text { problem due to Covid-19 is also there at any } \\
\text { member of the family }\end{array}$ & & $\sqrt{ }$ \\
\hline 3. & $\begin{array}{l}\text { Is there any member of your family who } \\
\text { concerns the most on your health problem/ } \\
\text { Covid- } 19 \text { problem at the moment? }\end{array}$ & $\sqrt{ }$ & \\
\hline 4. & $\begin{array}{l}\text { Has there been any change in your family since } \\
\text { you had this health problem or since this } \\
\text { pandemic happened? }\end{array}$ & $\sqrt{ }$ & \\
\hline 5. & $\begin{array}{l}\text { Do you think that your family could help } \\
\text { overcome your health problem that you are } \\
\text { having at the moment or when there is any } \\
\text { member of the family with a Covid-19-related } \\
\text { health problem.? }\end{array}$ & $\sqrt{ }$ & \\
\hline
\end{tabular}

Table 2 shows the description of the patient and his family's readiness in doing self-isolation at home, providing a special room with bathroom facility, rooms with windows for the exchange of air and sunlight exposure, readiness in providing food and medicine, and the ability to communicate online with a doctor and health officer.

TABLE II. THE DESCRIPTION ON THE PATIENT AND HIS FAMILY'S READINESS FOR SELF-ISOLATION

\begin{tabular}{|c|l|c|c|}
\hline No & \multicolumn{1}{|c|}{ Self-Isolation Readiness. } & Yes & No \\
\hline 1. & $\begin{array}{l}\text { A room separated from the other members of } \\
\text { the family for you }\end{array}$ & $\sqrt{ }$ & \\
\hline 2. & $\begin{array}{l}\text { A bathroom and toilet in the room } \\
\text { An openable window for air-exchange and } \\
\text { sunlight exposure }\end{array}$ & $\sqrt{ }$ & \\
\hline 4. & $\begin{array}{l}\text { Provision of food needed everyday from the } \\
\text { family }\end{array}$ & $\sqrt{ }$ & \\
\hline 5. & $\begin{array}{l}\text { Medicine procured by the family } \\
\text { Online communication with doctors and } \\
\text { health officer can be done everyday }\end{array}$ & $\sqrt{ }$ & \\
\hline & \multicolumn{2}{|l}{} & \\
\hline
\end{tabular}

Based on Table 1 and Table 2, actually the patient would have had the readiness and good family support if he had taken the self-isolation at home, but as the patient was worried about infecting the other members of the family, the patient decided to self-isolate in a place provided by the local government. During a pandemic, people are fearful that they or their family members will fall ill and are very uncertain of the repercussion of the pandemic. Furthermore, discrimination and stigma related to infectious diseases might make people fearful of infection, which can also affect their mental health status [15]. Previous studies reporting on the effects of quarantine in past epidemics and pandemics such as SARS, Ebola, the 2009 and 2010 H1N1 flu, Middle Eastern respiratory syndrome and equine influenza pandemics, were carried out in adult individuals [16-25]. In these studies, mood deflection and an increase in depression and anxiety are the most frequently reported psychopathological features in the general population. Recent studies among Italian [26] and Iranian [27] populations found that fear of COVID-19 was significantly correlated with depression and anxiety, as measured by the hospital anxiety and depression scale; the authors also explained that fear of COVID-19 may be exacerbated by coexisting depression and anxiety disorders [26].

The Patient Health Questionnaire (PHQ) is a new instrument for making criteria-based diagnoses of depressive and other mental disorders commonly encountered in primary care. At 9 items, the PHQ depression scale (which we call the PHQ-9) is half the length of many other depression measures, has comparable sensitivity and specificity, and consists of the actual 9 criteria upon which the diagnosis of Diagnostic and Statistical Manual of Mental Disorders 4th edition (DSM-IV) depressive disorders is in accordance with Mental Disorder Diagnosis Classification Guidelines-III used in Indonesia [8]. PHQ-9 score interpretation is None (Score 0-4), mild depression (Score 5-9), moderate depression (Score 10-14), moderate-severe depression (score 15-19), and severe depression (score 20-27) [28]. Table 3 shows depression screening result in the patient using Patient Health Questionnaire-9 with score 5. Screening result with PHQ-9 shows that the patient was under a mild depression condition. 
TABLE III. DEPRESSION SCREENING WITH PATIENT HEALTH QUESTIONNAIRE (PHQ-9)

\begin{tabular}{|c|c|c|c|c|c|}
\hline No & $\begin{array}{c}\text { Over the last } 2 \text { weeks, how often have you been disturbed with the following } \\
\text { problems }\end{array}$ & Never & $\begin{array}{l}\text { Severa } \\
\text { l days }\end{array}$ & $\begin{array}{l}\text { More than half the } \\
\text { days }\end{array}$ & $\begin{array}{l}\text { Almost every } \\
\text { day }\end{array}$ \\
\hline 1. & Not interested or excited about doing anything & & $\sqrt{ }$ & & \\
\hline 2. & Feeling despondent, gloomy, or losing hope & $\sqrt{ }$ & & & \\
\hline 3. & Trouble falling or staying asleep, or sleeping too much & & $\sqrt{ }$ & & \\
\hline 4. & Fatigue or listlessness & & $\sqrt{ }$ & & \\
\hline 5. & Little appetite or overeating & & $\sqrt{ }$ & & \\
\hline 6. & $\begin{array}{l}\text { Feeling inferior or thinking that you are a failure or disappointing yourself or } \\
\text { family }\end{array}$ & $\sqrt{ }$ & & & \\
\hline 7. & $\begin{array}{l}\text { Having difficulty concentrating on one activity, for example reading newspapers } \\
\text { or watching TV }\end{array}$ & & $\sqrt{ }$ & & \\
\hline 8. & $\begin{array}{l}\text { Moving or speaking so slowly that others might have noticed. Or the other way } \\
\text { around, feeling anxious and restless so that you have been moving more than } \\
\text { usual }\end{array}$ & $\sqrt{ }$ & & & \\
\hline 9. & Feeling it is better for you to die or wanting to hurt yourself in some way & $\sqrt{ }$ & & & \\
\hline
\end{tabular}

Generalized Anxiety Disorder (GAD) is an anxietyscreening questionnaire consisting of 7 questions with the score starting from 0 to 2 . GAD-7 score classifies anxiety into four degrees, that is: score $0-5$; mild anxiety; score 6-10 moderate anxiety; score 11-15; severe anxiety; and score $\geq 16$; very severe anxiety [29]. Table 4 shows the anxiety screening result in patient using GAD-7 was score 13, meaning that the patient suffered from moderate anxiety.

TABLE IV. ANXIETY SCREENING WITH GAD-7

\begin{tabular}{|c|c|c|c|c|c|}
\hline No & $\begin{array}{l}\text { Please fill in according to your thoughts, feelings, and } \\
\text { behaviours over the last } 2 \text { weeks, how often have you } \\
\text { been bothered by the following problems? }\end{array}$ & $\begin{array}{l}\text { Not at all in the } \\
\text { past } 2 \text { weeks }\end{array}$ & $\begin{array}{l}\text { Several days in } \\
\text { the past } 2 \text { weeks }\end{array}$ & $\begin{array}{c}\text { Over half the } \\
\text { days in the past } 2 \\
\text { weeks }\end{array}$ & $\begin{array}{c}\text { Almost everyday } \\
\text { in the past } 2 \\
\text { weeks }\end{array}$ \\
\hline 1. & Feeling nervous, anxious or restless & & & $\sqrt{ }$ & \\
\hline 2. & Being unable to stop or control worrying & & & $\sqrt{ }$ & \\
\hline 3. & Worrying too much over many things & & & $\sqrt{ }$ & \\
\hline 4. & Difficulty feeling relaxed & & & $\sqrt{ }$ & \\
\hline 5. & Being so restless that it is difficult to sit still. & & $\sqrt{ }$ & & \\
\hline 7. & Feeling worried as if something bad would happen. & & & $\sqrt{ }$ & \\
\hline
\end{tabular}

Table 4 shows the complaints felt by the patient consisting of the feeling of nervousness or anxiety, worries, difficulty feeling relaxed, and becoming easily upset. A patient confirmed with Covid-19 generally shows signs like refusal, regret, helplessness, anxiety, phobia, irritability, and sleep deprivation. Psychological evaluation in the isolation room demonstrated that $48 \%$ of the Covid-19-confirmed patients suffered from psychological stresses upon entering, an emotion response to stress [30]. A study involving 30 patients in a Covid-19 quarantine house showed that the most complaints were psychological complaints such as feeling anxious, tense/worried $(40 \%)$, followed with the complaints on neglected daily activity complaints/tasks (37\%), loss of appetite (30\%) and poor sleeping (30\%). Feeling anxious was due to their having to stay in an unfamiliar quarantine home, not their own home. Worrying about their health condition and the certainty of how long they will stay in the quarantine house. Being in a quarantine house made their activities and daily activities become limited. The anxiety condition also impacted their appetite and ability to sleep. 10 respondents, a third of the clients $(33,3 \%)$ living in the quarantine house due to Covid 19 pandemic, suffered from emotional mental disorder [10].
During the patients' self isolating in a place provided by the local government, the patients' health condition were always monitored. Communication with the family at home was arranged online. For the infected people in self- isolation, it is mandatory to keep away from the public to prevent further infections to others [29]. They are counseled to continuously seek medical assistance and stay in touch with doctors because the consequences from the severity of the virus can be fatal. Ensure to get help and support if breathing difficulty or other emergency warning signs are found $[13,14]$. Furthermore, they are also required to resume personal treatments and medications as they have to maintain a healthy condition in order to be cured [14]. Lastly, it is important to remind that any course of actions that exercise selfishness should be refrained in order to prevent the possibility of spreading the disease to other innocent people [12].

The patients needed not only medical care but also psychological support. Psychological support can be applied among others by using the suitable body language during the treatment of Covid-19 patients. As body motion and language of the health worker also affected the patients suffering from anxiety. Besides, psychological support can come from the 
patients' family, which will impact in the reduction of anxiety or depression of the patients during the isolation period [31].

\section{CONCLUSION}

The case of Covid-19 positive confirmed with mild symptoms can cause emotion disorder expressed in depression and anxiety. The readiness to self isolate at home does not guarantee to prevent the worries from infecting the other members of the family. Besides the treatment to relieve the symptoms, family support is really needed by Covid-19 positive confirmed in undergoing self isolation.

\section{ACKNOWLEDGMENT}

We would like to pass our deepest gratitude to doctors and other health workers, who have been struggling in handling Covid-19. This writing was inspired by the experience of the author in interacting with Covid-19 confirmed cases who underwent the self isolation.

\section{REFERENCES}

[1] Kementrian Kesehatan Republik Indonesia, Pedoman Pencegahan dan Penanggulangan Coronavirus Disease (COVID-19), 2020. [Online] Retrieved from: https://covid19.go.id/storage/app/media/Protokol/REV05_Pedoman_P2_COVID-19_13_Juli_2020.pdf. [Cited 2020 Oct 1].

[2] H.R. Güner, I. Hasanoğlu, and F. Aktaş, "COVID-19: Prevention and control measures in community," Turkish Journal of medical sciences, vol. 50, pp. 571-577, 2020

[3] Satgas Penanganan Covid-19, Peta Sebaran Kasus. Kementrian Kesehatan Republik Indonesia, 2021. [Online] Retrieved from: www.covid19.go.id

[4] J. Gralton, E.R. Tovey, M.L. McLaws, and W.D. Rawlinson, "Respiratory virus RNA is detectable in airborne and droplet particles," Journal of medical virology, vol. 85, pp. 2151-2159, 2013.

[5] Centers for Disease Control and Prevention, Ways COVID-19 Spreads, 2020. [Online] Retrieved from: https://www.cdc.gov/coronavirus/2019. ncov/prevent-getting-sick/how-covid-spreads.html

[6] M.K. Prakash, "Quantitative COVID-19 infectiousness estimate correlating with viral shedding and culturability suggests $68 \%$ presymptomatic transmissions," medRxiv, 2020. https://doi.org/10.1101/2020.05.07.20094789.

[7] Kementrian Kesehatan Republik Indonesia. Protokol Isolasi Mandiri COVID-19, 2020. [Online] Retrieved from: http://p2ptm.kemkes.go.id/kegiatan-p2ptm/dki-jakarta/protokol-isolasimandiri-COVID-19

[8] Centers for Disease Control and Prevention, Isolate if You Are Sick, 2021. [Online] Retrieved from: https://www.cdc.gov/coronavirus/2019ncov/if-you-are-sick/isolation.html

[9] Centers for Disease Control and Prevention, Coping with Stress, 2021. [Online] Retrieved from: https://www.cdc.gov/coronavirus/2019-ncov/ daily-life-coping/managing-stress-anxiety.html

[10] S. Nurjanah, "Gangguan Mental Emosional pada Klien Pandemi Covid 19 Di Rumah Karantina,” Jurnal Ilmu Keperawatan Jiwa, vol. 3, pp. 329-334, 2020.

[11] S. Sherchan, R. Samuel, K. Marahatta, N. Anwar, M.H. Van Ommeren, and R. Ofrin, "Post-disaster mental health and psychosocial support: experience from the 2015 Nepal earthquake," WHO South-East Asia journal of public health, vol. 6, pp. 22-29, 2018.
[12] P. Suppawittaya, P. Yiemphat, and P. Yasri, "Effects of social distancing, self-quarantine and self-isolation during the COVID-19 pandemic on people's well-being, and how to cope with it," International Journal of science and healthcare research, vol. 5, pp. 1220, 2020

[13] X. Marchand-Senécal, R. Kozak, S. Mubareka, N. Salt, J.B. Gubbay, A. Eshaghi, and J.A. Leis, "Diagnosis and management of first case of COVID-19 in Canada: lessons applied from SARS-CoV-1," Clinical Infectious Diseases, vol. 71, pp. 2207-2210, 2020.

[14] Kementrian Kesehatan Republik Indonesia, Protokol Isolasi Diri Sendir dalam Penanganan COVID-19, 2020. [Online] Retrieved from: https://covid19.kemkes.go.id/download/SE_MENKES_202_2020_proto kol_isolasi_diri_COVID.pdf

[15] B. Person, F. Sy, K. Holton, B. Govert, and A. Liang, "Fear and stigma: the epidemic within the SARS outbreak," Emerging infectious diseases, vol. 10 , pp. 358,2004

[16] R.J. Blendon, J.M. Benson, C.M. DesRoches, E. Raleigh, K. TaylorClark, "The public's response to severe acute respiratory syndrome in Toronto and the United States," Clin. Infect. Dis., vol. 38, pp. 925-931, 2004

[17] G. Caleo, J. Duncombe, F. Jephcott, K. Lokuge, C. Mills, E. Looijen, and J. Greig, "The factors affecting household transmission dynamics and community compliance with Ebola control measures: a mixedmethods study in a rural village in Sierra Leone," BMC public health vol. 18, pp. 1-13, 2018.

[18] M.A. Cava, K.E. Fay, H.J. Beanlands, E.A. McCay, R. Wignall, "The experience of quarantine for individuals affected by SARS in Toronto," Public Health Nurs, vol. 22, pp. 398-406, 2005.

[19] C. DiGiovanni, J. Conley, D. Chiu, and J. Zaborski, "Factors influencing compliance with quarantine in Toronto during the 2003 SARS outbreak," Biosecur. Bioterror, vol. 2, pp. 265-272, 2004.

[20] L. Hawryluck, W.L. Gold, S. Robinson, S. Pogorski, S. Galea, R. Styra, "SARS control and psychological effects of quarantine, Toronto, Canada," Emerg. Infect. Dis., vol. 10, pp. 1206-1212, 2004.

[21] H. Jeong, H.W. Yim, Y.J. Song, M. Ki, J.A. Min, J. Cho, and J.H. Chae, "Mental health status of people isolated due to Middle East Respiratory Syndrome," Epidemiol. Health, vol. 38, e2016048, 2016

[22] S. Lee, L.Y.Y. Chan, A.M.Y. Chau, K.P.S. Kwok, and A. Kleinman, "The experience of SARS-related stigma at Amoy Gardens," Soc. Sci. Med., vol. 61, pp. 2038-2046, 2005.

[23] U. Pellecchia, R. Crestani, T. Decroo, R. Van Den Bergh, and Y. AlKourdi, "Social consequences of ebola containment measures in Liberia," PLoS ONE, vol. 10, 2015.

[24] J.A. Wilken, P. Pordell, B. Goode, R. Jarteh, Z. Miller, B.G. Saygar, L. Maximore, W.M. Borbor, M. Carmue, and G.W. Walker, "Knowledge, attitudes, and practices among members of households actively monitored or quarantined to prevent transmission of ebola virus diseasemargibi county, liberia: February-march 2015." Prehosp. Disaster Med. vol. 32, pp. 673-678, 2015.

[25] M.K. Yoon, S.Y. Kim, H.S. Ko, and M.S. Lee, "System effectiveness of detection, brief intervention and refer to treatment for the people with post-traumatic emotional distress by MERS: a case report of community-based proactive intervention in South Korea," International journal of mental health systems, vol. 10, pp. 1-5, 2016.

[26] P. Soraci, A. Ferrari, F.A. Abbiati, E. Del Fante, R. De Pace, A. Urso, and M.D. Griffiths, "Validation and psychometric evaluation of the Italian version of the Fear of COVID-19 Scale," International Journal of Mental Health and Addiction, pp. 1-10, 2020.

[27] D.K. Ahorsu, C.Y. Lin, V. Imani, M. Saffari, M.D. Griffiths, and A.H Pakpour, "The fear of COVID-19 scale: development and initial validation," International journal of mental health and addiction, pp. 1-9, 2020.

[28] K. Kroenke, R.L. Spitzer, and J.B. Williams, "The PHQ-9: validity of a brief depression severity measure," Journal of general internal medicine, vol. 16, pp. 606-613, 2001. 
[29] S. Kertz, J. Bigda-Peyton, and T. Bjorgvinsson, "Validity of the Generalized Anxiety Disorder-7 Scale in an acute psychiatric sample," Clinical psychology \& psychotherapy, vol. 20, pp. 456-464, 2013.

[30] T. Liang, Handbook of COVID-19 Prevention and Treatment. Zheijing University School of Medicine, 2020. [Online] Retrieved from: https://kebijakankesehatanindonesia.net/review-publikasi/4082-bookhandbook-of-covid-19-prevention-and-treatment

[31] A.R. Jannah, A. Jatimi, M.J.A. Heru, Z. Munir, and H.F. Rahman, "Kecemasan Pasien COVID-19: A Systematic Review," Jurnal Penelitian Kesehatan SUARA FORIKES (Journal of Health Research Forikes Voice), vol. 11, pp. 33-37, 2020. 